doi:10.18575/msrs.sm.e.17.09 UDC 615.381:616.9-036.22 COBISS.RS-ID 6399512

\title{
First Results in Genotyping for Blood Donors of the Republic of Srpska with Serological Weak D Antigen
}

\begin{abstract}
Introduction: The Rh system is very complex, polymorphous and the most significant for clinical practice, along with the ABO blood group system. The $D$ antigen is the most important antigen in the Rh system and the most immunogenic one, following the $\mathrm{ABO}$ antigens. The $\mathrm{D}$ antigen, which consists of a mosaic of epitopes, is determined in all the blood donors and patients. Most people are either $\mathrm{RhD}$ positive or RhD negative, but there is a certain number of people who have a variation of the $D$ antigen, which are called weak $D$, partial $D$ and $D E L$ phenotypes.
\end{abstract}

Aim of the Study: The objective is to use molecular methods to determine whether blood donors in the Republic of Srpska (with whom a serological weak D antigen has been detected) really have the weak $D$ antigen, partial $D$, a combination of these two variants or if their $D$ antigen is normally present, but the used anti-D serum tests did not have the avidity needed to prove the presence of this antigen in blood donors.

Patients and Methods: Blood samples were used from regular blood donors, who had been determined as persons with a weaker D antigen (based on the agglutination strength) using serological techniques, the test tube method, the microplate method and the gel method. To determine the blood groups and red blood cell/erythrocyte antigen typing, the following methods were applied: a) test tube method or agglutination in an aqueous environment, b) gel method, c) microplate method and d) molecular determination of blood groups.

Results: Blood group samples were collected from April 2016 to February 2017 in the Institute for Transfusion Medicine of Republika Srpska. During this period, blood was collected from 8153 voluntary donors. It was serologically proved that 40 donors $(0.49 \%)$ had the weak $D$ antigen. All results where the weak $D$ antigen was determined serologically were confirmed by molecular testing. 23 respondents were proved to have weak D type $3(0.28 \%)$, while 17 had weak D type $1(0.20 \%)$.

Conclusion: The results from the first molecular testing of our population is in accordance with the results of frequency of weak $D$ antigen in the populations of other European countries, though it did show a small advantage of weak D type 3 over weak D type 1.

Keywords: The Rh system, antigen D, weak D, partial D, molecular method

\section{Gordana Guzijan', Marko Lilić, Biljana Jukić, Milanka Milosavić, Sandra Mitrović ${ }^{1}$}

${ }^{1}$ Institute for Transfusion Medicine of Republika Srpska, Banja Luka, Bosnia and Herzegovina

${ }^{2}$ Josip Juraj Strossmayer

University of Osijek, Osijek, Croatia

\section{Contact address:}

Gordana Guzijan

Street Address: Jovana Jančića 3

$780 o$ o Banja Luka,

Republic of Srpska

Bosna and Herzegovina

e-mail:gordanaguzijan@yahoo.com

phone number: +387-65-829-649
Submitted: February 18 ${ }^{\text {th }}, 2017$ Accepted: March 2 ${ }^{\text {nd }}, 2017$ 


\section{Introduction}

The Rh system is very complex, polymorphous and the most significant for clinical practice, along with the ABO blood group system. The $\mathrm{D}$ antigen is the most important antigen in the $\mathrm{Rh}$ system and the most immunogenic one, following the ABO antigens. The terms " $\mathrm{Rh}$ positive" and "Rh negative" refer to the presence or absence of the $\mathrm{D}$ antigen. In the mid-1940s, four anti-liquid antigens were identified: $\mathrm{C}$ and $\mathrm{c}, \mathrm{E}$ and $\mathrm{e}$. They were named by Fisher, who continued the nomenclature established by Landsteiner with the ABO system. Even though 50 antigens of this system have been discovered to this date, a set of five basic antigens, which are also called the Rh phenotypes, are responsible for the formation of the most clinically significant antibodies with Rh specificities. ${ }^{1,2}$

The Rh system consists of 50 antigens, ranging from Rh 1 to $\mathrm{Rh} 57$. There are several theories regarding the genetic inheritance of the system $\mathrm{Rh}$ antigens. At present, it is clear that there are two gene structures, RHD and RHCE and that the RHD gene encodes the formation of the $\mathrm{D}$ antigen, while the RHCE gene is responsible for the formation of the $\mathrm{CE}$ antigen in various combinations (ce, cE, Ce or CE). Molecular testing has confirmed the accuracy of this theory. These two genes have opposite orientations on the chromosome, but are identical to a large extent (approximately 97\%), and each consists of ten exons. As opposed to most blood groups systems whose antigens are coded by one gene, the Rh system antigens are coded by two genes. The fact that these genes are located on the same chromosome very close to one another refers to the possibility of exchange of material between them and explains the complexity of the $\mathrm{Rh}$ system. The exchange between the genes RHD and RHCE leads to the formation of new polymorphic proteins which are responsible for the emergence of a multitude of antigens belonging to the Rh system. . $^{1,2,3-6}$ Genes which control the Rh system antigens are located on the chromosome 1p36.13-p34.3. ${ }^{1,6}$

Approximately $85 \%$ of Caucasians are RhD positive, as well as approximately 95\% of the population in Africa south of Sahara and approx. 99,5\% of people in the eastern Asia. It has been determined that between 1 and 2\% persons of European descent has one of the D antigen variants, while their frequency is higher with the African population..$^{7,8}$

The D antigen is presented as a mosaic of epitopes, and those individuals whose erythrocytes do not have some of those parts (following the exposure to the complete $\mathrm{D}$ antigen) form anti-D antibody against the missing epitope. In contact with a normal D antigen, this antibody behaves as any other anti-D antibody. Most people are either RhD positive or RhD negative, but there is a certain number of people who have a variation of the $\mathrm{D}$ antigen, which are called weak D, partial D and DEL phenotypes.

The term D weak has traditionally meant the complete D antigen, which has all the epitopes, but weakly expressed. For a number of years, it was considered that separation of the phenotype D weak from partial D had significance for clinical practice, because individuals with the phenotype D weak will not form anti-D antibody after receiving D-positive blood, given that their $\mathrm{D}$ antigen is normally built, even though being weaker.

As opposed to them, it was considered that individuals with partial D can form anti-D antibody (after receiving D-positive blood) against the part of the $\mathrm{D}$ antigen which they are lacking, and should therefore only receive D-negative blood. ${ }^{-11}$

However, this assumption was diminished after it was noted that polypeptide $\mathrm{D}$ with individuals with the phenotype weak D is not normally built and that people with this phenotype can form anti-D antibody. Many examples of D weak and partial D have been examined on the molecular level. ${ }^{12-17}$

This is how it was concluded that it is very important to separate weak D from partial D antigen in the clinical practice, because patients with the $\mathrm{D}$ weak phenotype will not form anti-D antibody after the application of D-positive blood (given that their antigen is weakened, but normal). As opposed to them, patients with partial $\mathrm{D}$ antigen can be immunized on the part of the $\mathrm{D}$ antigen they themselves are lacking and should therefore receive transfusion with D-negative blood.

Detection of anti-D antibodies with individuals with weak D type 15 has shown that this division is not sufficiently clear or precise, if the definition that only individuals with partial D form anti-D antibody is correct. Essentially, the phenotype D weak type 4.2 is functionally identical to the partial antigen DAR, even though it has been described that erythrocytes of these two phenotypes lead to formation of anti-D antibodies in recipients. ${ }^{10}$

Erythrocytes of the phenotype weak D type 2 have the lowest density of all the most common types of the weak D antigen. Therefore, Flegel and associates have recommended that erythrocytes of the phenotype weak D type 2 are a threshold for the detection of anti-D test reagents and should be used as part of quality control in routine immunohematological work. ${ }^{18}$ This is why the validity of the assumption that individuals with a weak D phenotype cannot form anti-D antibody and that they cannot cause an immune response with D-negative recipients has been questioned..$^{10-11}$ 
With his research, Flegel has showed that there are different nucleotide substitutions in the RHD gene which lead to the exchange of amino acids in the erythrocytes samples with the weak D phenotype, which indicate their abnormal structure and individuals with this phenotype can form anti-D antibody. ${ }^{12-17}$

The so-called partial RhD phenotypes were marked as DIIIa, DVI, DBT and DFR. They can mutually be separated by serological and molecular methods, and at least one individual with any of these phenotypes has formed anti-D antibody. Forms of weaker D phenotype are marked with numbers from weak D type 1 to weak D type 135, and there are also a number of intermediate forms (for instance, weak D.-4.2), where the number continues to rise.

These weaker forms of $\mathrm{D}$ antigen are connected to a smaller expression of the D antigen on the erythrocyte membrane, but they can be mutually differentiated exclusively by the application of molecular test methods. More to this, some forms, especially the phenotypes of the weak D.-4.2, -15 and -21 have been determined in patients who have formed anti-D antibody. ${ }^{19-20}$ The most common of the weakly expressed D antigen is type 1, which is determined by the mutation $809 \mathrm{~T}>\mathrm{G}$ in exon 6 .

Single nucleotide polymorphism, SNP, in the gene is expressed as the mutation $\mathrm{V} 270 \mathrm{G}$ in the $\mathrm{RhD}$ protein and together with types 2 and 3, it represents approximately $90 \%$ of the weak D phenotypes found in individuals of European descent. ${ }^{21-22}$ The weakly expressed D antigen type 3 is determined by the mutation $8 \mathrm{C}>\mathrm{G}$ in exon 1 . The SNP in the gene RHD is expressed as the mutation $\mathrm{S}_{3} \mathrm{C}$ in the $\mathrm{RhD}$ protein.

According to the published data, from the overall number of tested samples, the frequency of weak D type 1 is $70 \%$, for weak D type $218 \%$, while the frequency for weak D type 3 is $5 \%$. Weak D type 1 and type 3 are typical for the haplotype DCe, weak D type 2 for the haplotype DcE. ${ }^{19,20-}$ 23

\section{Aim of the Study}

1. The objective is to use molecular methods to determine whether blood donors in the Republic of Srpska (with whom a serological weak D antigen has been detected) really have the weak D antigen, partial D, a combination of these two variants or if their $\mathrm{D}$ antigen is normally present, but the used anti-D tests serum did not have the avidity needed to prove the presence of this antigen in blood donors;

2. The objective is to determine the frequency of the proven weak and partial D antigens and compare it with the frequency of weak and partial D antigens in other Caucasians.

\section{Patients and Methods}

Blood samples were used from regular blood donors, who had been determined as persons with a weaker D antigen (based on the agglutination strength) using serological techniques, the test tube method, the microplate method and the gel method, according to the instruction of the manufacturer of the test serum.

Two blood samples were taken from each respondent, with EDTA in the amount of $5 \mathrm{ml}$ : one for the serological confirmation of the respondent's RhD status, and the other for molecular examinations.

To determine the blood groups and red blood cell/ erythrocyte antigen typing, the following immunoserological methods were applied, according to the described standard operating procedures:

1. The test tube method or agglutination in an aqeous environment. The reaction takes place in the test tube following the mixing of erythrocyte suspension and test serum. Test serums of a known specific quality are used to determine the presence or absence of a certain antigen (serums of Biognost Zagreb, Novaclone Canada, Sanguin Holland, Immucor USA, Diagast France), whereas erythrocytes of an identified phenotype are used to detect antibodies. ${ }^{24-26}$

2. Gel method.This method is based on the use of microtube plates containing gel particles. Each gel card contains six microtubes for six equal or different tests. Gel particles are spherical and have the function of reaction media and filter in the test. They contain erythrocyte agglutinate, and they let free erythrocytes through to the bottom. In that way, the reading of the gel particles reaction result is easier and harmonized. ${ }^{24-27}$

3. Microplate method. This method is used to determine erythrocyte antigens or antibodies. Small amounts of erythrocytes and test serums are added to microplate tubes, which are then centrifuged. Erythrocytes are resuspended from the bottom of the recess by putting the plate on the mixer or by manually shaking the plate, whereafter the reaction is being read either manually or by an automatic reader. In the case of negative reaction, erythrocytes are fully resuspended in the serum, without any visible agglutinates. The advantage of this method as opposed to the conventional tube agglutination method is the lower 
consumption of reagents. ${ }^{24,25}$

4. In this study, the process implies automatic examination of $\mathrm{ABO}$ and $\mathrm{RhD}$ antigen blood groups, as well as Rh phenotypes from the donor's samples on the device Techno (DiaMed), ${ }^{28}$ by applying the microplate method, as well as the gel method, by DiaMed test serums. In this way we have electronic entry in the Lira reader and any error in copying is being avoided. Serological examination of $\mathrm{D}$ antigen variants with the commercial panel (BioRad, Diagast).

5. Molecular determination of blood groups, with special reference to the $\mathrm{D}$ antigen.

Molecular diagnostics in terms of proving the RHD gene will be done on all blood donors who are serologically confirmed to be RhD-negative, as is the case with individuals with Ccddee and ccddEe phenotypes, or those with serologically weak positive D antigen. FluoGene is a unique method for molecular examination of HLA, erythrocyte and thrombocyte genes, which combines all the SSP-PCR, i.e. polymerase chain reactions and speed the fluorescent detection has as the final point of examination. The analysis is based on the specifically modified system TaqMan ${ }^{\circledR}$ tests, fluorescence of which is detected in the Fluo Vistadevice of the manufacturer Inno-train Diagnostik, Germany. Advantages of this method are: a) PCR-SSP method without gel electrophoresis, by which the analysis is made in 90 minutes; b) there is no hybridization and washing processes; c) the overview of the gained results is fully objective, software-wise, immediately following the reading; d) there is no risk of post-PCR contamination; d) DNA consumption is low; e) the software is easy to use, it has a completely automatic reading of the results. ${ }^{29}$

Additional advantages of the Fluogene system include the testing possibility to get the results of low DNA concentration samples $(\mathrm{c}<10 \mathrm{ng} / \mu \mathrm{L})$, as well as minimum risk of sample contamination, which remain sealed during the test. ${ }^{29}$

FluoGene tests: DNA is isolated by the isolation method on silicone colons that have the specific ability to connect and release the DNA in puffers of different $\mathrm{pH}$ (Ready DNA Isolation Spin Kit, Inno-train Diagnostik, Germany). Following the DNA isolation, the testing plate is prepared (tests: RBC-Fluogene Dweak/variant and RBC-Fluogene CDE,Inno-train Diagnostik, Germany) and it contains primers lyophilized in advance in the wells and TaqMan tests by pipetting the mixture FluoMixa (containing DNA, dNTP, Mg2+, Taq polymerase) and DNA according to the instructions of the manufacturer. The primers are dependent on the sequences of certain gene variants determined to, as a rule, have primers in each well for mutually different DNA segments. The prepared plate was put in the FluoVista apparatus to have the basic fluorescence intensity (pre-PCR) read. In accordance with the manufacturer's protocol, the polymerase chain reaction (PCR) was done in 40 cycles, in the apparatus Eppendorf - vapo.protect, mastercycler (Eppendorf, Germany). Following the PCR in the apparatus FluoVista, the fluorescence intensity was read after the PCR (postPCR). For the positivity of the well, the difference between post-PCR and pre-PCR fluorescence intensity is essential. The wells where the difference in intensity is above the level defined by the manufacturer were marked as positive. The software automatically calculated the difference between the fluorescence intensity and determined the Dweak type, i.e. RHD and/or RHCE phenotype, which was displayed as the result for the envisaged phenotype on RHD and/or RHCE locus.

\section{Results}

Blood group samples were collected from April 2016 to February 2017 in the Institute for Transfusion Medicine of Republika Srpska. During this period, blood was collected from 8153 voluntary donors. It was serologically proved that 40 donors $(0.49 \%)$ had the weak $\mathrm{D}$ antigen (Table 1).

Table 1. The number of tested RhD samples

\begin{tabular}{|cc} 
RhD & $n(\%)$ \\
\hline RhD + & $6791(83.29)$ \\
RhD - & $1322(16.22)$ \\
Rh D weak & $40(0.49)$ \\
TOTAL & $8153(100.0)$ \\
\hline
\end{tabular}

The respondents belonged to the category of regular blood donors, who had donated blood at least twice before this study and who were serologically proven to have weak D. Their results upon the testing of presence of the markers for transfusion transmissible diseases were negative.

In the sample, most of the blood donors were men (31 donor, $77.5 \%$ ) while 9 donors were women (22.5\%). This was expected given that men are more represented as blood donors in our population (approximately $82 \%$ ) as opposed to women (approximately 18\%).

The analysis of $\mathrm{Rh}$ phenotypes showed most of the respondents were found to have the $\mathrm{Rh}$ phenotype 
CcDwee - 39 (97.5\%) and only one had the phenotype CCDwee (2.5).

All results where the weak D antigen was determined serologically were confirmed by molecular testing. In 23 respondents, it was proved that they had weak D type 3 (0.28\%), while 17 had weak D type 1 (0.20\%) (Table 2).

Table 2. Molecular testing of the samples serologically proven as weak $D$

\begin{tabular}{cc}
\hline D weak & $\mathrm{n}(\%)$ \\
\hline D weak type 1 & $17(0.20)$ \\
\hline D weak type 3 & $23(0.28)$ \\
TOTAL & $8153(100.0)$ \\
\hline
\end{tabular}

\section{Discussion}

The prevalence of the serologically proven weak D phenotype varies among races and nations. ${ }^{30}$ These forms of the weak D antigen are most proven $\mathrm{D}$ variants in Europe and the USA. It is estimated that 0.2\% to 1.0\% Caucasians inherits the RHD gene, which encodes the formation of the serologically weak D phenotype.

Most often, these are weak D types 1,2 and $3 \cdot{ }^{30-32}$ The results of the prevalence of the serologically weak D phenotype also vary depending on the applied test method (manual test tube method as opposed to automatic testing), the anti-D reagents used (polyspecific serum as opposed to monoclonal blend) and on the use of reaction enhancers (bromelin). ${ }^{33}$ Most data on RHD alleles and risk of alloimmunization in serologically weak D phenotypes result from studies conducted in central Europe. ${ }^{30,34-37}$ These studies indicate that blood recipients, who have weak D type 1,2 or 3 , in a homozygous or hemizygous form, do not have a risk of forming anti-D antibody after receiving $\mathrm{RhD}$-positive erythrocytes with normally expressed D. ${ }^{35,36}$

Approximately 95\% of Caucasians in central Europe who have been determined to have the weak $\mathrm{D}$ antigen have the weak D type 1, 2 or 3. They are treated as RhDpositive and can receive $\mathrm{RhD}$-positive blood transfusions. The absence of anti-D antibodies in individuals of the mentioned phenotypes seems to be the consequence of the fact that different RHD alleles encode formation of all epitopes of the RhD antigen in these individuals, as opposed to individuals with normally expressed D antigen, even though the antigen density on the surface of the erythrocyte with weak D type 1, 2 or 3 is smaller than the ones with normal D. ${ }^{30}$
The alloimmunization to the $\mathrm{D}$ antigen and anti-D antibody was proven with some other types of weak D antigen, such as weak D type DAR,,$^{30}$ type $11,3^{35,37}$ type $15,,^{35,37}$ type $21^{38}$ and type $57 .{ }^{39}$

The results from the first molecular testing of our population is in accordance with the results of frequency of weak D antigen in the populations of other European countries, ${ }^{30,34-37}$ although it did show a small advantage of weak D type 3 in relation to weak D type 1 . This initial study has showed that the algorithm of serological testing of the D antigen in the Institute for Transfusion Medicine Republika Srpska correlates with the current immunohematological practice in the world..$^{40}$ Fluogene method is reliable, precise, fast and very suitable for molecular determination of RHD and RHCE phenotype. The results are available within 2 hours of the test start. ${ }^{41}$

\section{Conclusion}

The first molecular examinations on frequency of weak D antigens in the population of blood donors of the Republic of Srpska pointed to good results in the application of contemporary immunohematological recommendations in the testing of D antigens with blood donors in the Institute for Transfusion Medicine Banja Luka, but they also pointed to the necessity of applying the same testing mode in all centers in the Republic; it further pointed to the necessity of determining the frequencies of all RHD alleles in the Republic of Srpska, in order to improve the immunohematological testing of $\mathrm{D}$ antigens with blood donors and pregnant women by introducing molecular methods in the routine work; the first results showed that the donors who were molecularly confirmed to have the weak D antigen belonged to the categories that were treated as RhD-positive, and should they need blood they may also receive $\mathrm{RhD}$-positive blood. This is how RhD-negative blood reserves are preserved. This examination should be expanded on all pregnant women with serologically weak D antigen, in order to determine those that have weak forms 1, 2 and 3 and do not have to receive $\mathrm{RhD}$ immunoprofylaxis, so that the reserves of this valuable immunoglobulin may be preserved.

\section{References}

1. Jackson JC. Adverse events associated with exchange transfusion in healthy and ill newborns. Pediatrics 1997; 99:E7.

https://doi.org/10.1542/peds.99.5.e7 PMid:9113964

2. Milosavljević J, Veljković D. Rizik prenošenja hepatitisa transfuzijom $\mathrm{u}$ današnjim uslovima. U:Marjanović B, urednik:Problemi u pedijatriji ‘88. Beograd: Naučna knjiga 1989; s.302-18.

3. Popović M, Radunović N, Antonović O. Lečenje 
visokorizičnih $\mathrm{Rh}$ aloimunizovanih trudnica plazmaferezama i intrauterusnim transfuzijama. Bilt hematol transfuziol 1988; 16(1). Abstrakt.

4. Plećaš D, Radunović N, Popović M, Ljubić A, Mirković Lj. Tri stotine pedeset intrauterinih intravaskularnih transfuzija u lečenju hemolitičke bolesti fetusa. I Kongres transfuziologa Jugoslavije sa međunarodnim učešćem, Beograd 1998; 44(2):98. (Abstrakt).

5. Schumacher B, Moise KJ. Fetal transfusion for red blood cell alloimmunization in pregnancy. Obstet Gynecol 1996; 88(1): 137-50.

https://doi.org/10.1016/oo29-7844(96)oo113-5

6. Alonso JG, Decaro J, Marrero A. Repeated direct fetal intravascular high-dose immunoglobulin therapy for the treatment of Rh hemolytic disease. J.Perinatal Med 1994; 22: 41-5-9.

7. Knight R. Fundamentals of Biomedical Science. Transfusion and Transplantation Science. Transfusion Science Consultant. Oxford, University Press, 2013.

8. Daniels G. Human Blood Groups, 3rd ed. Wiley Blackwell, 2013.

https://doi.org/10.1002/9781118493595

9. Klein HG, Anstee DJ, The Rh blood group system (including LW and RHAG) In: Klein HG, Anstee DJ.

10. Daniels G. Rh and RHAG blood group systems. In: Daniels G. Human Blood Groups. 3nd ed. Wiley-Blackwell Science, 2013; p.182- 259. https://doi.org/10.1002/9781118493595.ch5

11. Westhoff CM. Review: The Rh blood group D antigen. Dominant, diverse, and difficult. Immunohematology 2005; 21: 155-63.

PMid:16472017

12. Lomas C, McColl K, Tippett P. Further complexities of the $\mathrm{Rh}$ antigen D disclosed by testing category DII cells with monoclonal anti-D. Transfus Med. 1993; 3: 67. https://doi.org/10.1111/j.1365-3148.1993.tbo0106.x PMid:7518725

13. Gorick B, Dougall DCJ, Ouwehand WH et al. Quantification of D sites on selected "weak D and "partial" D red cells. Vox Sang 1993; 65:136-40. https://doi.org/10.1111/j.1423-0410.1993.tbo2130.x PMid:7692673

14. Agre PC, Davies DM,Issitt PD. et al. A proposal to standardize terminology for weak D antigen. Transfusion 1992; 32:86-7.

https://doi.org/10.1046/j.1537-2995.1992.32192116441.x PMid:1731444

15. Contreras M. Knoght RC. Controversies in transfusion medicine: testing for Du:Con. Transfusion 1991; 31:270-2. https://doi.org/10.1046/j.1537-2995.1991.31391165180.x

16. Scott ML, Voak D, Liu W et al. Epitopes on Rh proteins. Vox Sang 2000; 78(Suppl 2):117-20. PMid:10938939

17. Arce MA, Thompson ES, Wagner S, et al. Molecular cloning of RhD cDNA derived from a gene present in $\mathrm{RhD}$-positive, but not RhDnegative individuals. Blood 1993; 82: 651-5. PMid:8329718

18. Flegel WA, Wagner FF. Molecular Biology of partial D and weak D:Implications for Blood Bank Practice. Clin.Lab. 2002; 48:53-9. PMid:11833677

19. Wagner FF, Frohmajer A, Ladewig B et al. Weak D alleles express distinct phenotypes. Blood 2000; 95:2699-708. PMid:10753853

20. McGann H, Wenk RE. Alloimmunization to the D antigen by a patient with weak type 21. Immunohematology 2010;26:27-29. PMid:20795315

21. Flegel WA, Wagner FF. Molecular Biology of partial D and weak D: Implications for Blood Bank Practice. Clin. Lab 2002; 48:53-9. PMid:11833677

22. Mota M, Fonseca N, Rodriguez A, Kutner JM, Castillo L. Anti-D alloimmunisation by weak D type 1 red blood cells with a very low antigen density. Vox Sang 2005; 88:13035 .

https://doi.org/10.1111/j.1423-0410.2005.00604.x PMid:15720611

23. Wagner FF and Flegel WA (2014) The Rhesus Site. Transfus Med Hemother 41(5): 357-363. PMID: 25538538 https://doi.org/10.1159/000366176

24. Judd J, Johnson JT, Storry J. Judd's methods in immunohematology. 3rd ed.Bethesda, Md: AABB Press, 2008.

25. Jovanović Srzentić S., Veljković D. Imunobiološki i klinički značaj krvnih grupa. IntraNet Communication, Beograd, 2009.

26. Rodgers RP. Clinical Laboratory Methodsfor Detection of Antigen and Antibodyes.In: Stites DP, Terr AI, Parslow TG.Editors. Basic and Clinical Immunology.Connecticut: Appleton and Lange, 1994.p.151-95.

27. Voak D. The status of new methodsfor detection of red cell agglutination.Transfusion 1999; 39:1037:40.

28. McNeilC, HelminckW, FerariA. Apreliminaryinvestigation into automatic blood grouping.Vox Sang 1963: 8:235-7. https://doi.org/10.1111/j.1423-0410.1963.tbo3299.x PMid:13932229

29. Williams M (1), Boam S (1), Maley M (1), Nightingale MJ (1), Ash C (1), Finning K (2) Assessment and Validation of Fluogene System for Genotyping Patients Referred to RCI Laboratories (1), NHS Blood and Transplant, (2) International Blood GroupReference Laboratory (IBGRL), Bristol.Blood and transplant.

30. Flegel WA. How I manage donors and patients with a weak D phenotype. CurrOpinHematol 2006; 13:476-83. https://doi.org/10.1097/01.moh.0000245694.70135.c3

31. Fung MK, Grossman BJ, Hillyer CD, et al., editors. Technical manual 18th ed. Bethesda (MD): American 
Association of Blood Banks; 2014

32. Wagner FF, Gassner C, Müller TH, et al. Molecular basis of weak D phenotypes. Blood 1999; 93: 385-93. PMid:9864185

33. Müller TH, Wagner FF, Trockenbacher A et al. PCR screening for common weak D types shows different distributions in three Central European populations. Transfusion 2001; 41:45-52 https://doi.org/10.1046/j.1537-2995.2001.41010045.x PMid:11161244

34. Garratty G. Do we need to be more concerned about weak D antigens; Transfusion 2005; 45:1547-1551. https://doi.org/10.1111/j.1537-2995.2005.00625.x PMid:16181202

35. Westhoff CM. Review: the Rh blood group D antigen... dominant, diverse, difficult. Immunohematology 2005; 21: 155-63.

PMid:16472017

36. Hemker MB, Ligthart PC, Berger L, et al. DAR, a new $\mathrm{RhD}$ variant involving exons 4,5 , and 7 , often in linkage with ceAR, a new Rhcevariant frequently found in
African blacks. Blood 1999; 94: 4337-42. PMid:10590079

37. Flegel WA. How I manage donors and patients with a weak D phenotype. CurrOpinHematol 2006; 13:476-83. https://doi.org/10.1097/01.moh.0000245694.70135.c3

38. Pham BN, Roussel M, Peyrard T, et al. Anti-D investigations in individuals expressing weak D Type 1 or weak D Type 2: allo-or autoantibodies; Transfusion 2011; 51:267985.https://doi.org/10.1111/j.1537-2995.2011.03207.x PMid:21658048

39. Wagner FF, Frohmajer A, Ladewig B, et al. Weak D alleles express distinct phenotypes. Blood 2000; 95: 2699-708. PMid:10753853

40. Jovanović Srzentić S., Antić A, Radonjić Z. Imunohemato loškadijagnostikaaloimunizacija u trudnoći. Caligraf soft. Beograd, 2016.

41. Assessment and Validation of Fluogene System for Genotyping Patients Referred to RCI Laboratories M. Williams,1 S. Boam,2 M. Maley,3 K. Finning,4 M. Nightingale5 \& C. Ash6 Transfusion Medicine, 2014, 24, Suppl. 2, 72 .

\section{Prvi rezultati u genotipizaciji serološki slabih oblika $D$ antigena kod davalaca krvi u Republici Srpskoj}

\section{SAŽETAK}

Uvod: Sistem Rh je veoma kompleksan, polimorfan i, pored sistema ABO, najznačajniji za kliničku praksu. Antigen D je najvažniji antigen sistema Rh i najimunogeniji poslije antigena ABO. Svim davaocima krvi i pacijentima određuje se antigen D, koji je sačinjen od mozaika epitopa. Većina ljudi je ili RhD pozitivna ili RhD negativna, ali postoji i određen broj osoba sa varijantama antigena $\mathrm{D}$, takozvanim slabim $\mathrm{D}$ ( $\mathrm{D}$ weak), parcijalnim $\mathrm{D}$ i fenotipom DEL.

Cilj rada: Molekularnim metodama utvrditi da li davaoci krvi u populaciji Republike Srpske, kod kojih je serološki određen slab oblik antigena D, zaista imaju slabo izražen antigen D, parcijalni antigen D, kombinaciju ova dva tipa, ili je njihov antigen D normalno izražen, ali korišćeni anti-D test serum nije imao aviditet dovoljan za dokazivanje ovog antigena kod davalaca krvi;

Ispitanici i metode: Koristili smo uzorke krvi redovnih dobrovoljnih davalaca koji su, na osnovu jačine aglutinacije, serološkim tehnikama, metodom u epruveti, metodom u mikroploči i metodom u gelu određeni kao osobe sa slabije izraženim antigenom D. Za određivanje krvnih grupa i tipizaciju eritrocitnih antigena koristili su se sljedeće imunoserološke metode, prema opisanim standardnim operativnim procedurama: a) Metoda u epruveti ili aglutinacija u tečnoj sredini; b) Metoda u gelu; c) Metoda u mikropločama; d) Molekularno određivanje krvnih grupa.

Rezultati: Uzorci dobrovoljnih davalaca su prikupljeni u periodu od aprila 2016.god. do februara 2017.god. u Zavodu za transfuzijsku medicinu Republike Srpske. U tom periodu je prikupljena krv od 8153 davaoca. Kod 40 davalaca (0,49\%) je serološki dokazan slab D antigen. Svi ispitanici kojima je serološki dokazan slab D antigen su potvrđeni i molekularnim testiranjem. Kod 23 ispitanika je dokazan D weak tip 3 (0,28\%), a kod 17 ispitanika D weak tip 1(0,20\%).

Zaključak: Prva molekularna ispitivanja naše populacije u skladu su sa rezultatima ispitivanja o učestalosti slabog antigena $D$ u populacijama drugih naroda Evrope, mada malu prednost ima slabi D tip 3 u odnosu na slabi D tip 1.

Ključne riječi: Th Rh sistem, D antigen, slabi D (Dweak), parcijalni D, molekularna metoda 